International Journal of Chemical and Process Engineering Research

2014 Vol. 1, No. 1, pp. 1-9

$\operatorname{ISSN}(e): 2313-0776$

$\operatorname{ISSN}(p): 2313-2558$

DOI: $10.18488 /$ journal.65/2014.1.1/65.1.1.9

(C) 2014. Conscientia Beam. All Rights Reserved.

(CrossMark

\title{
SEASONAL VARIATION OF THE WATER QUALITY OF THE SENEGAL RIVER (MAURITANIA)
}

\author{
Abdoulaye Demba N'DIAYE ${ }^{1}$--- Mohamed Ould Sid' Ahmed Ould KANKOU ${ }^{2}$ \\ ${ }^{1,2}$ Research Unit of Water, Pollution E Environnement,Department of Chemistry, Faculty of Science and Technology, \\ Mauritania
}

\begin{abstract}
The aim ofthis studyis to monitor and to assessthe physicochemicalwater qualityof the river Senegal during the rainy and dry season. The conventional physico-chemical parameters ( $p H, E C$ and DO), dissolved and suspended particles (turbidity and TSS), OM and nitrateswere considered in this study. The samples are collected at the Beni Nadji site between February and November 2012. The values of the measured parameters were compared with WHO standards for drinking water quality. The findings show that all the physicochemical parameters measured were within the tolerable values except the turbidity and TSS that exceeded with respectively the maximum values of $980 \mathrm{NTU}$ and $674 \mathrm{mg} / \mathrm{L}$ for the rainy season only. The analysis of the correlation matrix can be noted strong correlations between the turbidity and TSS (0.996), turbidity and OM (0.924), TSS and OM (0.931), nitrates and TSS (0.814), nitrates and turbidity (0.800) and nitrates and $O M$ (0.744). These strong correlations allow us to say that these parameters are governed by the same mechanism or phenomenon that could possibly be leaching during the rainy season. Therefore, frequent monitoring of physicochemical parameters of Senegal River water resources is imperative.
\end{abstract}

Keywords: Physicochemical, Water, Quality, Correlation, Senegal river, Mauritania.

\section{INTRODUCTION}

The water quality parameters on the right bank of the Senegal River in Mauritania have been studied earlier reports [1,2].

Hence, the present study was conducted to study the physico-chemical parameters of this river water in different seasons of the year. In this context, the use of PCA (Principal Component Analysis) for the interpretation of the data seems an interesting solution to a better understanding of water quality and ecological status of the media studied. This technique also has the advantage of identifying and linking the various factors (sources) to the 
observed effects on aquatic systems. It is a best tool for managing water resources to find quick solutions to pollution problems [3-5]. This method is widely used to interpret the hydrochemical data $[6,7]$.

\section{MATERIALS AND METHODS}

\subsection{Study Area}

TheSenegal River basinis locatedin the western partof Africa.It is drainedby ariver $1800 \mathrm{~km}$, the second longest inthis regionof Africa. TheSenegal River basinis shared byfour countries:Guinea, Mali, Mauritania andSenegal(Figure 1).

This river is used as such as for drinking, fishing, irrigation and other domestic purposes. The hydrological regime is quite pure tropical, with a unimodal annual flood, varies from one year to another. The period of high water lasts from July to November, followed by a drying will from December to June, with an occasionalstopflows. Thewater management consists of two dams Diama andManantali [8].

All field work has been done on the study area on the right bank of the Senegal River specifically at one sampling location Beni Nadji (BN), seven kilometers from Moughataa Keur Macene (Figurer-1).

\subsection{Samplings Collection and Analytical Determination}

Sampling was carried daily from $1^{\text {st }}$ February to 30 st November 2012. The samples in polyethylene bottles with a capacity of $1 \mathrm{~L}$ kept in thermostats and transported to Laboratory Quality Control of Beni Nadji and Laboratory of Water Chemistry from National Institute for Research in Public Health to Nouakchott City. The physicochemical parameters studied are the potential Hydrogen (pH), Electrical Conductivity (EC), Turbidity, Total Suspended Solids (TSS), the Oxidizables Matters (OM), Dissolved Oxygen (DO) and nitrates $\left(\mathrm{NO}_{3}{ }^{-}\right)$. The $\mathrm{pH}$ was measured by a $\mathrm{pH}$ meter Wagtech. The EC was measured by a conductimeter Wagtech. Oxygen-meter Hach Lange Sension 6 type was used to determine the DO and is expressedin $\mathrm{mg} / \mathrm{L}$. Turbidity was measured by a Turbidimeter type Hach Lange P 2100 and expressed in NTU. TSS was measured using a photometer from Hach Lange DR 890. The OM is determined by oxidation in acidic medium with potassium permanganate. $\mathrm{NO}_{3}{ }^{-}$was measured by a Photometer DR 5000 with nitrate pastilles.

\subsection{Statistical Analysis}

Statistical analysis was based on the PCA. For data processing by the PCA, we used seven variables: $\mathrm{pH}, \mathrm{EC}, \mathrm{OM}$, TSS, turbidity, DO and nitrates as 304 samples (304 factors corresponding to numbers of samplings days) between the $1^{\text {st }}$ of February and $30^{\text {th }}$ of the November 2012 on the basis of a single site (Beni Nadji). Intermediate correlation matrix was obtained with XLSTAT 2012 Software. 


\section{RESULTS}

\subsection{Temporal Evolution of theWater Quality from the Senegal River}

The values of $\mathrm{pH}$ recorded between February and June vary with a minimum value of 7.7 and a maximum value of 8 (Figure 2). From July to November the $\mathrm{pH}$ values ranging from a minimum value of 7.4 and a maximum value of 7.7 (Figure 2). The EC values between February and June, ranged from $54.9 \mu \mathrm{S} / \mathrm{cm}$ to $92 \mu \mathrm{S} / \mathrm{cm}$ (Figure 3). From July to November, there is a gradual decreasing in the EC values ranging from a minimum value of $41.2 \mu \mathrm{S} / \mathrm{cm}$ and a maximum value of $83.2 \mu \mathrm{S} / \mathrm{cm}$ (Figure 3 ).

Concentrations of DO obtained between February to June vary between $2.9 \mathrm{mg} / \mathrm{L}$ and 8.2 $\mathrm{mg} / \mathrm{L}$ (Figure 4). Between July and November, the concentrations of DO obtained vary from 2.1 $\mathrm{mg} / \mathrm{L}$ to $7.2 \mathrm{mg} / \mathrm{L}$ (Figure 4 ).

The minimum value obtained between February and June is 2.43 NTU and the maximum value observed is 13 NTU (Figure 5). By the beginning of July to November, corresponding to the period of heavy rains the values gradually increase up to a maximum value of $980 \mathrm{NTU}$ (Figure 5). We observe that from the month of February until June, the TSS varied from $1 \mathrm{mg} / \mathrm{L}$ to $11 \mathrm{mg} / \mathrm{L}$ (Figure 6). Between July and November corresponding to the period of heavy rains, the maximum value is $674 \mathrm{mg} / \mathrm{L}$ (Figure 6). The concentration OM recorded between February and June is a low, ranged from $0.3 \mathrm{mg} / \mathrm{L}$ to $3 \mathrm{mg} / \mathrm{L}$ (Figure 7). Between July and the November, the maximum concentration is $5.9 \mathrm{mg} / \mathrm{L}$ (Figure 7). The nitrates concentration of the Senegal River water was low between February and June, ranged from $0.3 \mathrm{mg} / \mathrm{L}$ to $6.6 \mathrm{mg} / \mathrm{L}$ (Figure 8). Between July and November we observe the highest value was $16 \mathrm{mg} / \mathrm{L}$ (Figure 8).

\subsection{Intermediate Matrix Correlations between Variables}

The Correlation Coefficient between various physico-chemical parameters are shown in Table1. The analysis of the correlation matrix can be noted strong correlations between the parameters turbidity and TSS (0.996), turbidity and $\mathrm{OM}(0.924)$, TSS and $\mathrm{OM}(0.924), \mathrm{NO}^{-}{ }_{3}$ and TSS (0.814), $\mathrm{NO}^{-}{ }_{3}$ and turbidity (0.800) and $\mathrm{NO}_{3}^{-}$and $\mathrm{OM}(0.744)$ (Table 1). DO present a strong and negative correlations with the turbidity $(-0,818)$, TSS $(-0,840)$, OM $(-0,833)$ and $\mathrm{NO}^{-}{ }_{3}(-0,831)$ (Table 1).

\section{DISCUSSION}

Aquatic organisms are affected by $\mathrm{pH}$ because most of their metabolic activities are $\mathrm{pH}$ dependent. Optimal pH range for sustainable aquatic life is $\mathrm{pH}$ between 6.5 and 8.2 [9]. No significant difference were recorded between seasons and months (Figure 2). The pH values obtained of the Senegal River water are within the standards for drinking water quality [10]. This study agreement with previous studies [1,2].

The EC reflects the overall degree of mineralization and the salinity. The minimum EC was recorded during the rainy season and the maximum was recorded during the dry season (Figure 
3). The EC values are within the standards for drinking water quality [10]. The decreasing of the EC values during the rainy season is due to dilution effect.The present study agrees earlier observation [1].

The DO is one of the most important indicators of the degree of water pollution. DO does not have any direct bearing on the health risks of humans but can predict the water quality of the system [11]. The minimum level of DO was recorded during rainy season and maximum level during dry season (Figure 4). The reason for the low DO content was due to high decomposition of organic matter, which indicates a high pollution load in the water. The negative and strong correlation observed between the DO and turbidity, TSS, OM and nitrate (Table 1) shows that the minimum level of DO was recorded during rainy season and maximum during dry season. It is reported by Radha, et al. [12] that the deficiency of the oxygen in the water is shelter for bacteria and other pathogens, which are anaerobic and injurious to human health.

Turbidity in water is caused by suspended and colloidal matter such as clay, silt, finely divided organic and inorganic matter, and plankton and other microscopic organisms [13]. It is noted that during the rainy season the very high level of turbidity (Figure 5).The turbidity values obtained during rainy season were higher than WHO standard limit of 5 NTU [10].

TSS is all mineral and organic particles in the water. Turbidity and TSS are the materials in water that affect the transparency or light scattering of the water. Their effects on the physicochemical characteristics of the water are very harmful (change in turbidity and reduced light penetration endangering photosynthesis) [13]. It is noted that during the rainy season the very high level of TSS (Figure 6). The TSS values obtained during rainy season were higher than WHO standard limit of $5 \mathrm{mg} / \mathrm{L}[10]$. It is noted that during the rainy season the very high level of TSS. This observation is similar with study conducted by Makhoukh, et al. [14].

The OM is representative of the majority of the organic oxidizable compound but also mineral salts. During rainy season its concentrationwas higher than the dry season (Figure 7). The OM values were a bottom the permissible limits as per WHO [10]. They are responsible for the color of the water has properties of ion exchangers and complexing properties.

The nitrates values obtained in the Senegal River water were a bottom the permissible limits as per WHO [10]. Nitrate exhibited higher value in rainy season and very low in dry season (Figure 8). The surface run of agricultural wastes fertilizers domestic wastes, house hold sewage and surface run off can also increases the concentration of nitrate[15].High concentration of nitrate in the water may be due to local run off from the adjacent crop fields where the farmers have used nitrogen fertilizers. The high concentration may be due to the influencedoxidation of the nitrogenous ammonia of nitrite to nitrate [15].

The strong correlations obtained between turbidity, TSS, OM and nitrate (Table 1) allow us to say that these parameters are governed by the same mechanism or phenomenon that could 
possibly be leaching during the rainy season. The rain can be a vehicle for the most toxic substances (heavy metals and pesticides).

We found that thepollution of Senegal River was observed during the rainy season characterized byhigh valuesturbidity and TSS. The physical and chemical compositions of Senegal river water is controlled by many factors such as natural (rain) and anthropogenic (domestic, industrial and agricultural activities). Increasing surface water pollution causes not only deterioration of water quality, but also threatens human health, balance of aquatic ecosystem, economic development and social prosperity. The good practice agriculture scheme should be implemented.

\section{CONCLUSION}

The water of the Senegal River showed, during the rainy season, respectively a very high turbidity and TSS of 980 NTU and $674 \mathrm{mg} / \mathrm{L}$. The present data indicated the turbidity and TSS are physical parameters considered as indicators of pollution parameters. Our present data should serve as baseline for future reference. It is time for national authorities to develop a network of quality control of the Senegal River in setting up sensors to continuously monitor the concentrations of $\mathrm{DO}$, turbidity, $\mathrm{pH}, \mathrm{EC}$, nitrates, etc.

\section{ACKNOWLEDGEMENTS}

The authors would like to thank Ousmane THIAM Header ofLaboratory Quality Control of Beni Nadji for his Technical Support.

\section{REFERENCES}

[1] M. Ould Kankou, "Vulnérabilité des eaux et des sols de la rive droite du fleuve Sénégal en Mauritanie," Thèse De Doctorat, L'université De Limoges, Option Chimie et Microbiologie De l'Eau, France, 2004.

[2] A. D. N’Diaye, M. S. K. Mint, M. B. EL Kory, M. O. S. A. Ould Kankou and M. Baudu, "Contribution to space and temporal study of the physicochemical quality of water from the Senegal river right bank," J. Mater. Environ. Sci., vol. 5, pp. 320-329, 2014.

[3] Y. Ouyang, "Evaluation of river water quality monitoring stations by principal component analysis," Water Res., vol. 39, pp. 2621-2635, 2005.

[4] S. Shrestha and F. Kazama, "Assessment of surface water quality using multivariate statistical techniques: A case study of the Fuji river basin, Japan," Environmental Modeling \& Software, vol. 22, pp. 464-475, 2007.

[5] A. Mencio and J. Mas-Pia, "Assessment by multivariate analysis of groundwater-surface water interactions in urbanized Mediterranean streams," J. Hydrol., vol. 352, pp. 355-366, 2008. 
[6] M. Jadal, M. EL Ayouchi and L. Bennasser, "Qualité des eaux de l'estuaire de l'oued Om Rbiâ (Maroc) et influence de la dynamique marégraphique," L'eau, L'industrie, Les Nuisances, vol. 256, pp. 59-66, 2002.

[7] M. EL Mohrit, M. Fekhaoui, A. Serghini, S. EL Blidi, A. EL Abidi, R. Bennakam, A. Yahyaoui and M. Jbilou, "Impact de l'aménagement hydraulique sur la qualité des eaux et des sédiments de l'estuaire du loukkos (Côte Atlantique, Maroc)," Bulletin De l'Institut Scientifique, Rabat, Section Sciences De La Terre., vol. 30, pp. 39-47, 2008.

[8] S. Sambou, S. Tamba, M. T. Cisse and Y. Dieme, "Prévision des crues dans le bassin amont du fleuve Sénégal a l'aide de procédures adaptatives," Revue Scientifique et Technique, LJEE No 21 et 22. Spécial Colloque CIREDD, 2013.

[9] V. Patel and P. Parikh, "Assessment of seasonal variation in water quality of river mini, at Sindhrot, Vadodara," International Journal of Environmental Sciences, vol. 3, 2013.

[10] WHO, Guidelines for drinking water quality, 3rd ed. Geneva, Switzerland: Recommendations, World Health Organization, 2006.

[11] L. Singh and S. K. Choudhary, "Physico-chemical characteristics of river water of Ganga in middle Ganga plains," International Journal of Innovative Research in Science, Engineering and Technology, vol. 2, pp. 4349-4357, 2013.

[12] K. R. Radha, K. Dharmaraj, and K. B. D. Ranjitha, "A comparative study on the physicochemical and bacterial analysis of drinking, borewell and sewage water in the three different places of Sivakasi," Journal of Environmental Biology, vol. 28, pp. 105-108, 2007.

[13] V. Roher, A. Groleau, N. Escoffier, E. Gacia-Gonzalez, J. Pouillaude, and S. Guerin, "Suivi en continu de la qualité des eaux de surface: Cas de la Seine," Technique Science Méthodes, pp. 18- 29, 2013.

[14] M. Makhoukh, M. Sbaa, A. Berrahou, and M. Van Clooster, "Contribution à l'étude physicochimique des eaux superficielles de l'oued Moulouya (Maroc Oriental)," Larhyss, vol. 9, pp. 149-169, 2011.

[15] K. P. Mahesh and C. Prabhahar, "Physico - chemical parameters of river water: A review," International Journal of Pharmaceutical \& Biological Archives, vol. 3, pp. 1304-1312, 2012.

Table-1. Intermediate matrix correlations between variables

\begin{tabular}{|c|c|c|c|c|c|c|c|}
\hline Variables & $\mathrm{pH}$ & EC & Turbidity & TSS & OM & DO & $\mathrm{NO}^{-}$ \\
\hline $\mathrm{pH}$ & 1 & & & & & & \\
\hline EC & 0,210 & 1 & & & & & \\
\hline Turbidity & $-0,196$ & $-0,446$ & 1 & & & & \\
\hline TSS & $-0,194$ & $-0,467$ & 0,996 & 1 & & & \\
\hline OM & $-0,194$ & $-0,521$ & 0,924 & 0,931 & 1 & & \\
\hline DO & 0,079 & 0,582 & $-0,818$ & $-0,840$ & $-0,833$ & 1 & \\
\hline $\mathrm{NO}^{-}$ & $-0,233$ & $-0,521$ & 0,800 & 0,814 & 0,744 & $-0,831$ & 1 \\
\hline
\end{tabular}


Figure-1. Map of localization of Senegal River and Samplings Collection
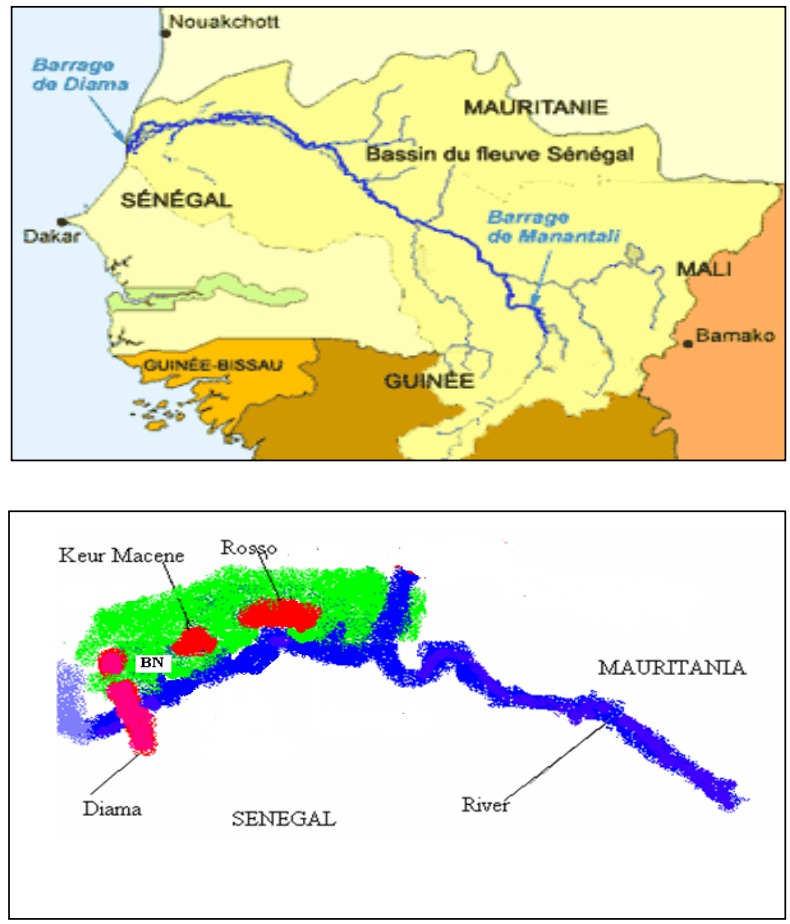

Figure-2. Temporal Evoluton $\mathrm{pH}$ values

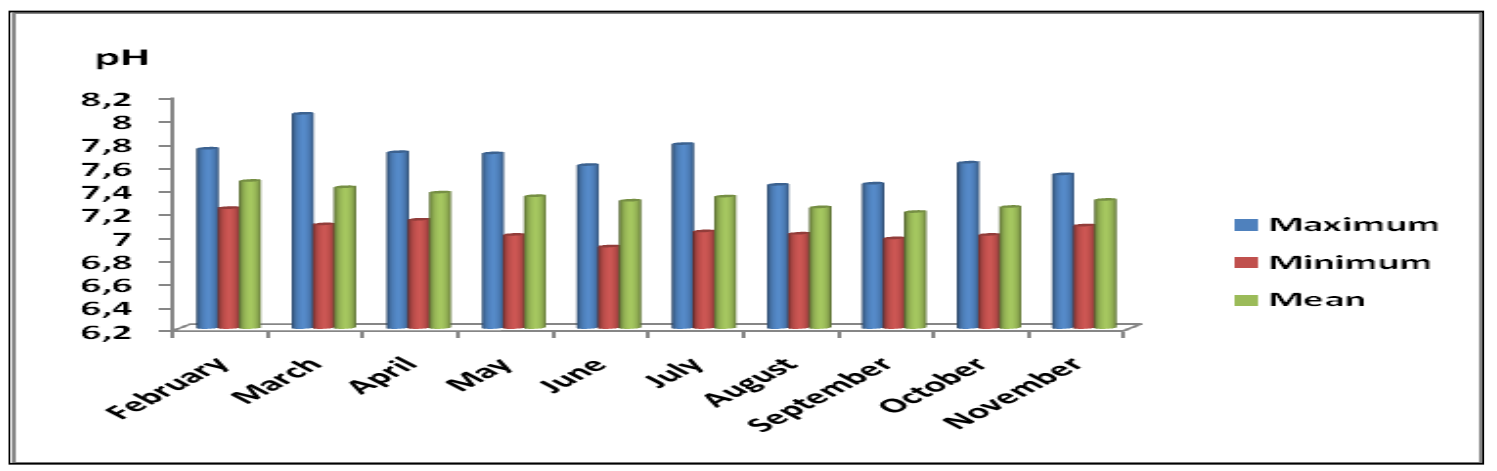

Figure-3. Temporal Evoluton EC values

\section{$\mathrm{CE}(\mu \mathrm{S} / \mathrm{cm})$}

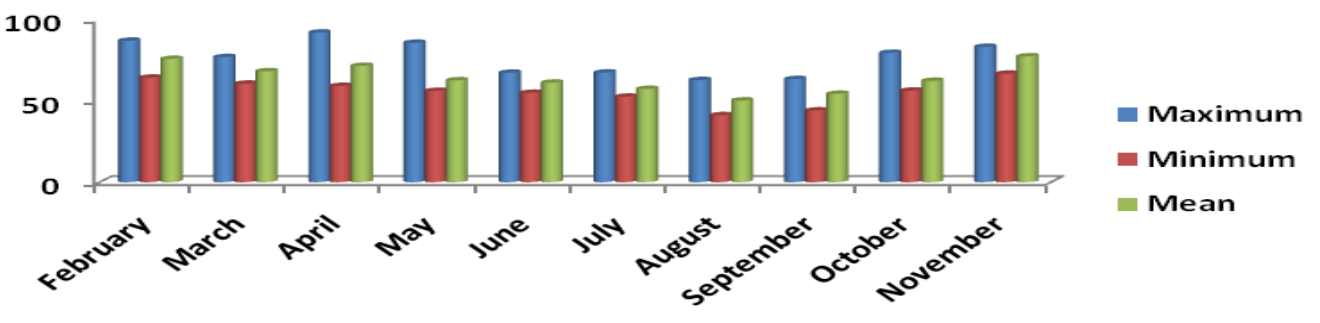


Figure-4. Temporal evolution of the amount of DO

\section{$\mathrm{DO}(\mathrm{mg} / \mathrm{L})$}

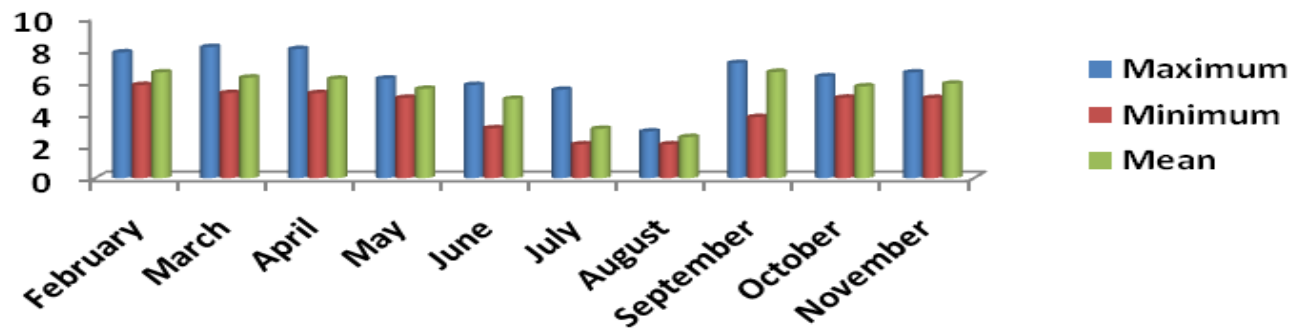

Figure-5. Temporal evolution of the amount turbidity

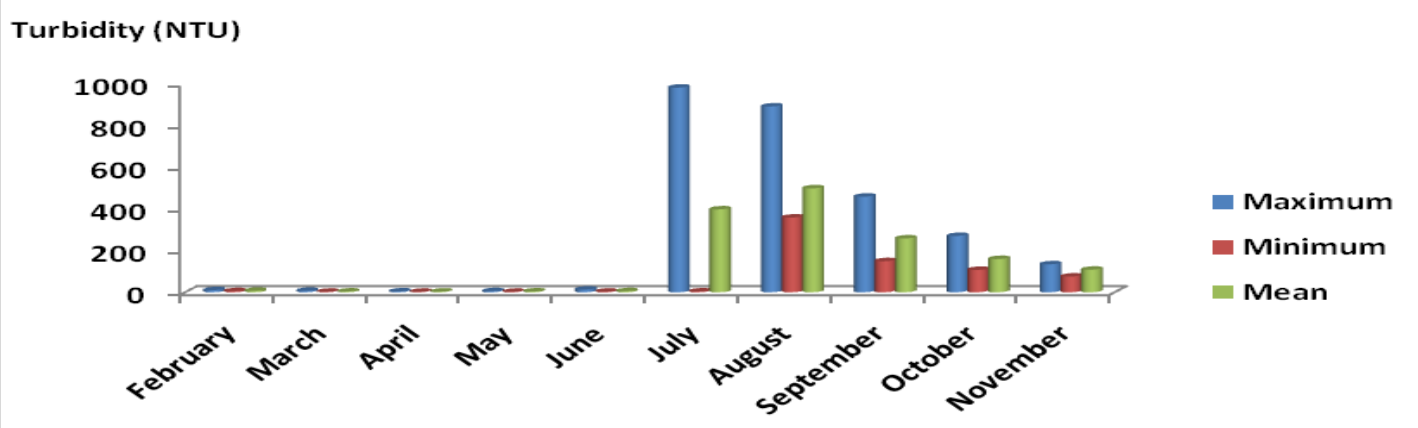

Figure-6. Temporal evolution of the amount TSS

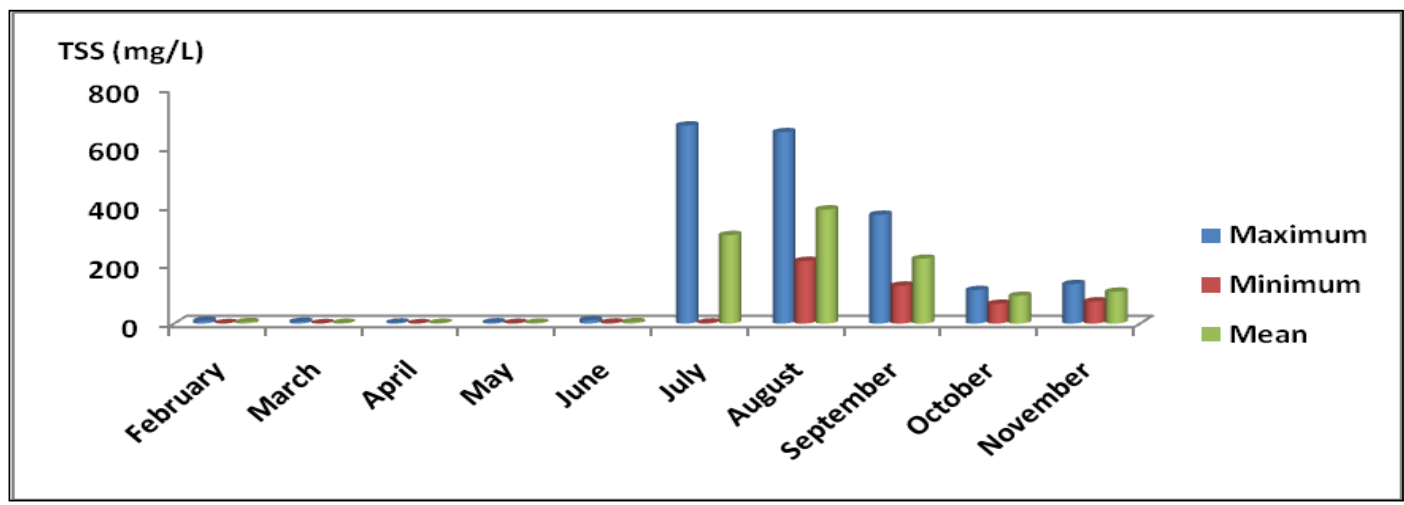


Figure 7. Temporal evolution of the amount of OM

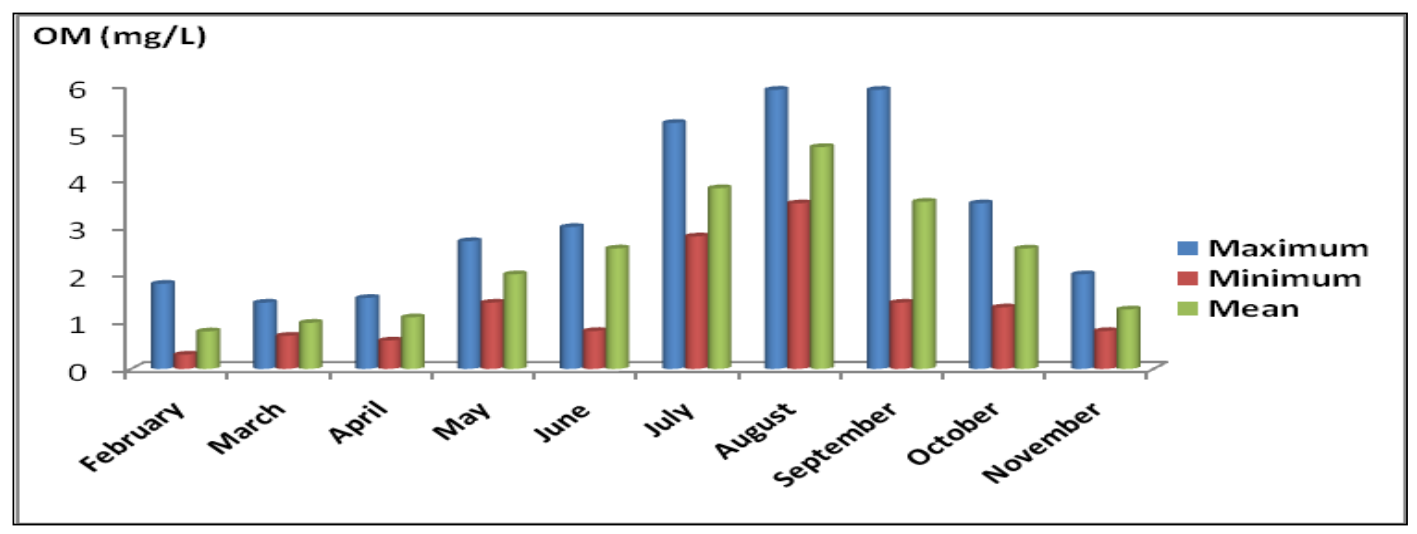

Figure 8. Temporal evolution of the amount Nitrate

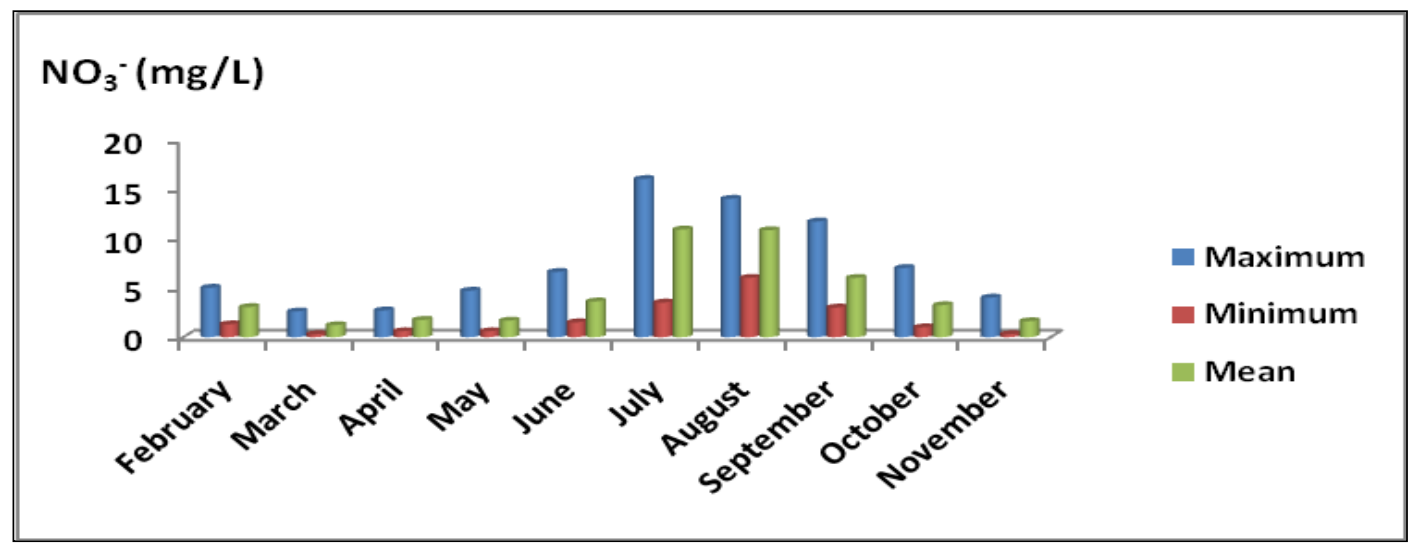

Views and opinions expressed in this article are the views and opinions of the author(s), International Journal of Chemical and Process Engineering Research shall not be responsible or answerable for any loss, damage or liability etc. caused in relation to/arising out of the use of the content. 